\title{
Tourism in natural protected areas in Mexico
}

\author{
O. Arizpe C. ${ }^{1}$, J. Urciaga $^{1}$ \& A. Arizpe-V. ${ }^{2}$ \\ ${ }^{1}$ Universidad Autónoma de Baja California Sur, Mexico \\ ${ }^{2}$ Universidad Autónoma de Baja California, Mexico
}

\begin{abstract}
The notable emergence of tourism, especially sustainable tourism, as a source of employment and economic resources, allows the opportunity of an alternative to economic and social activities. The Natural Protected Areas (NPAs) are fundamental instruments of environmental policies to preserve biodiversity and the ecological goods and services of a nation, and an engine of sustainable development. There are many institutions and international instruments that promote sustainable tourism as a strategy to preserve NPAs and their cultural resources, at the same time allowing the development of local economies. Mexico, which is one of the highest biodiversity countries of the world, has promoted NPAs as legal mechanisms to encourage the conservation of many regions all over the nation that have a unique biological processes and a high degree of conservation and/or preservation. The Mexican government has assumed the responsibility by establishing different instruments of environmental policies, particularly NPAs that include environmental programs based on regional analyses, different hydrological, economic, and social characteristics. The National Commission of Natural Protected Areas estimates that around 5.5 million tourists annually visit the 176NPAs of Mexico from across the country. The future management of NPAs in Mexico - 13\% of the country - is difficult, but shows good prospects especially in the state of Baja California Sur, which has the biggest coastline extension and highest NPA percentage in the country.NPA tourism is considered as a highly regarded opportunity for the development of Mexico's economy because it provides a significant value to the natural elements of the area, also increasing the quality of life in local communities and the health of the ecosystems.

Keywords: natural protected areas, sustainable tourism in Mexico.
\end{abstract}




\section{Introduction}

Presently, tourism is recognized as a growing worldwide economic activity and, most of the time its implication is vital for the economy of any country. The notable emergence of tourism, especially sustainable tourism, as a source of employment and economic resources, allows the opportunity of an alternative to economic activities [1]. The World Travel and Tourism Council (WTTC) establishes, as an example, that in 2007 the economical contribution of tourism was almost $10 \%$ of the world's GDP, and the same percentage new employees [2]. Mexico is recognized worldwide for its high biological diversity, both terrestrial and marine, framed in a region of large scenic attractiveness. Coastal plains, cliffs, bays lagoons, islands and islets, and its narrow but deep sea shape this beauty. Tourism is a relevant sector in the country with a continuous growing rate. In 2003, the income from tourism activity in Mexico was close to 9.4 billion dollars, increasing $5.5 \%$ over 2002 . The number of visitors who came to Mexico during the mentioned year was 18.8 million [3]. According to the tourism competitiveness of the World Economic Forum 2009 report, Mexico contributes: $13.3 \%$ of GDP around $\$ 276.9$ billion us dollars and $13 \%$ of employees (3.8 million).

The National Development Plan of Mexico 2007-2012 established tourism as a relevant sector for the Mexican economy including it also as a social and cultural factor substantial for the development of the country. This plan set the purpose of the country as a leader in tourism activity, increasing the quality and diversity of the services and infrastructure. For the first time this month, the National Institute of Statistics and Geography (INEGI) is including indicators of tourism activity. This indicator set for 2011 a growth rate of $2.2 \%$ over of 2010 .

\section{Natural protected areas in Mexico}

The acknowledgment of natural resources, even in its abstract perspective as landscape, and cultural capital (local ways of life and their traditions) is behind the dynamism of tourism and its consequent benefits. Tourism has been the prospect in which international organizations, led by the United Nations Educational Scientific and Cultural Organization (UNESCO), has been developed to promote the idea of sustainability. Thus, found in the internationalization of the natural and cultural wealth, a way to promote tourism and to find sources of funding for conservation and creating, for example, natural protected areas (NPA), which contribute to better social cohesion through the generation of public symbols of collective identity. A strong ally of UNESCO in the task to preserve and make known the sites of outstanding cultural or natural importance "for the common heritage of mankind" has been the International Union for Conservation of Nature (IUCN), founded in 1948 to coordinate protection and nature conservation policies among States Members. One of its main tasks was the creation of a coordinated system of nature reserves and national monuments. This program reinforced by initiatives of UNESCO, is the one known as Man and Biosphere (MAB). The Convention on Biological 
Diversity, the RAMSAR convention, the World Heritage Convention, the Convention on International Trade in Endangered Species of Wild Fauna and Flora (CITES) are some other examples of international agencies that promote sustainable tourism as a strategy to preserve NPAs and their cultural resources, at the same time allowing the development of local economies.

The NPAs are classified in terrestrial and marine portions of national territory, representing various ecosystems where the original environment has not been essentially altered and produce increasingly valued ecological benefits. The NPAs are fundamental instruments of environmental policies that preserve biodiversity and the ecological goods and services of the nation. They also function as an engine of sustainable development. The decree to constitute NPAs provided the legal infrastructure necessary to establish the management relations of ecosystems and natural resources and to organize local communities and relevant interests towards sustainable development. The NPAs are instruments for planning that represent conserved resources and become generating sources of socio economical and cultural benefits. Their importance lies in the storage of resources for human use, provision of essential services such as food production, water supply, public health, and some others. They provide refuge and key habitats, allowing the migration and movements of indigenous species, ensuring the maintenance of natural processes. They are the main source of potable water for more than a third of the largest cities in the world, and provide food security production for the planet [4]. The environmental or ecosystems services provided by the NPAs include reducing floods, unnatural forest fires, and control of erosion, and retaining and purifying water. Ecosystems in protected areas provide various benefits for natural resources and at all levels, local, national and global. At the global level, it has been estimated that the value of the benefits far surpass the costs. In addition to this, a variety of study cases found that the benefits of the conservation of biodiversity outweighs the benefits of converting habitats to extensive use in intensive agriculture or forestry land [4].

Table 1: $\quad$ Percentage of the natural protected areas. Source: world database on protected areas. http://www.wdpa.org/Statistics.aspx.

\begin{tabular}{|l|r|r|r|}
\hline \multicolumn{1}{|c}{ Country } & \multicolumn{1}{c|}{$\begin{array}{c}\text { Area } \\
\text { (ha) }\end{array}$} & \multicolumn{1}{c|}{$\begin{array}{c}\text { NPA surface } \\
\text { (ha) }\end{array}$} & $\begin{array}{c}\text { Percentage of } \\
\text { NPA (\%) }\end{array}$ \\
\hline Canada & $998,467,000$ & $15,306,499$ & 15.3 \\
\hline United States & $962,909,100$ & $151,273,020$ & 15.7 \\
\hline Costa Rica & $5,110,000$ & 903,959 & 17.7 \\
\hline United Kingdom & $24,290,000$ & $1,156,204$ & 4.8 \\
\hline China & $964,001,100$ & $154,818,577$ & 16.1 \\
México & $196,437,500$ & $23,258,200$ & 11.9 \\
\hline
\end{tabular}

In Mexico, the National Development Plan establishes sustainability as one of its fundamental principles. The development must be complete, preserving the environment, and reconstructing to benefit the ecosystems until it achieves 
harmony among humans themselves and with natural resources. Through many years, nature has not been properly valued; it has been contaminated without consideration. Almost twenty years ago it was recognized that development must be based on wildlife conservancy; otherwise, it would not be sustainable. Mexico has promoted the NPAs as a legal mechanism to encourage the conservation of high diversity areas that have unique biological processes and a high degree of conservation and/or preservation. The NPAs are increasing each year, spanning more than $10 \%$ of the country, a percentage that is considered a first-class quality standard of conservancy policy (Table 1).

The NPAs in Mexico are created by a presidential decree. The activities that can be conducted, legal regulations, the management plan and programs of ecological zoning for them, are established according to the General Law of Ecological Balance and Protection of the Environment (LGEEPA). They are subject to special regimes of protection, conservation, restoration and development, according to categories established by law [5]. By August 1992, a total of 71 NPAs had been decreed: 10 biosphere reserves (BR), 12 special biosphere reserves, 44 national parks (NP), two protected areas for wild flora and fauna (PAFF), and three natural monuments (NM). According to a report by the National Commission for Natural Protected Areas (CONANP), by 2013 at the federal level, 176 NPAs had been decreed. These were distributed in the following categories: 41 BR, 67 NP, 5 NM, 37 PAFF, 18 Sanctuaries (S) and 8 Natural Resources Protection Areas (NRPA). The National Commission of natural protected areas (CONANP) currently managing 176 federal natural areas representing more than 25,387,972 hectares, 13\% of Mexico extension (Table 2, Figure 1):

Table 2: $\quad$ Category, surface and number of NPA and percentage related to the national territory (CONANP, 2013).

\begin{tabular}{|c|l|r|c|}
\hline $\begin{array}{c}\text { PNA } \\
\text { number }\end{array}$ & \multicolumn{1}{|c|}{ Category } & Area (ha) & $\begin{array}{c}\text { Percentage in } \\
\text { Mexico (\%) }\end{array}$ \\
\hline 41 & Biosphere reserves & $12,652,787$ & 6.44 \\
\hline 67 & National parks & $1,445,301$ & 0.74 \\
\hline 5 & Natural monuments & 16,268 & 0.01 \\
\hline 8 & Natural resources protection areas & $4,440,078$ & 2.26 \\
\hline 37 & Flora and fauna protection areas & $6,687,284$ & 3.40 \\
\hline 18 & Sanctuaries & 146,254 & 0.07 \\
\hline
\end{tabular}




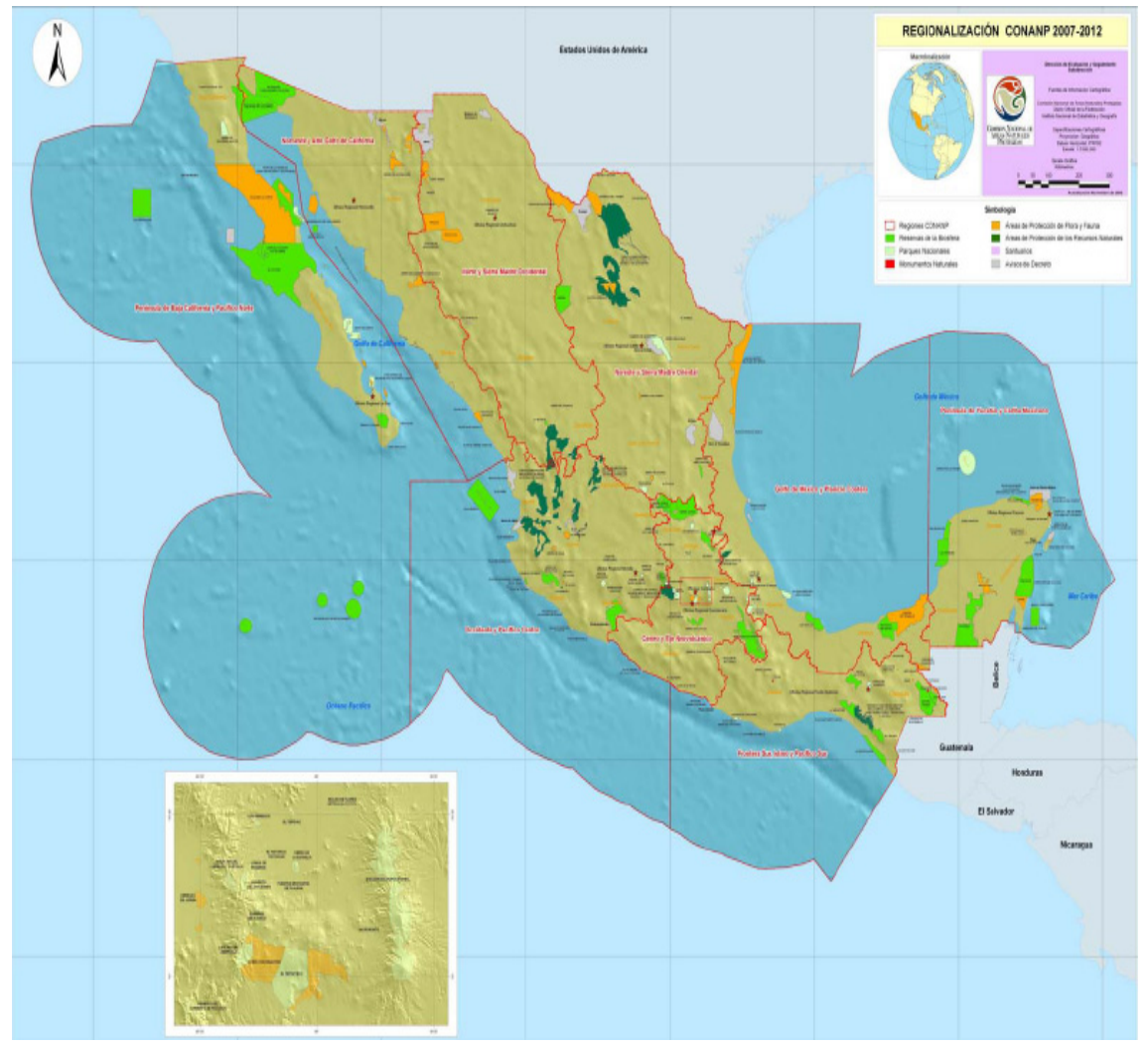

Figure 1: Mexican NPA in green and orange colors. http://www.conanp. gob.mx.

\section{Tourism in protected natural areas in Mexico}

Since the last century the number and growth rate of tourists to the protected areas have increased and currently is a global reality. However, this activity may threaten the cultural and natural heritage since there have been international experiences that demonstrate negative impacts on the natural, social and even economic context of protected areas. This growth in visitors, as well as the interest in handling it appropriately, is a phenomenon that is also replicated in Mexico within the NPAs. Studies of the Ministry of Tourism (SECTUR) have found that protected areas are the preferred destinations for ecotourism, nature and adventure tourism activities. The National Commission of Natural Protected Areas (CONANP) estimates that around 5.5 million tourists annually visit the NPAs from across the country. NPA tourism should be seen as a highly regarded opportunity for the development of Mexico because it provides a significant value to the natural elements of the area, increasing also the quality of life in local communities and areas surrounding the natural areas. The threats and 
opportunities presented on the other hand, depends on the type of tourism phenomenon and its conservation if it is managed wisely and in a sustainable way.

Development is related to the level of visitors, the characteristic of the visitor, and tourism investment and tourism impacts. Management - in the case of the CONANP - is related to the practices and applications of instruments, such as the collection of duties applied for the conservation of the protected areas. It has been observed that tourism is heterogeneous in the NPAs because in each of them there is a different level of stay that depends on various factors: its relation to the regional tourism context, the central attractions and the development of infrastructure and tourist services provided. At the same time it is apparent that for each protected area, tourist management is variable and is at different levels as they depend on institutional capabilities and resources of the NPA.

From this perspective, it is necessary to create policies and guidelines at the institutional level to address the needs and the specific opportunities of each NPA at the national level, as well as establish a common thread which induces the different actors at federal and local levels to create synergies in order to achieve common objectives towards sustainable comprehensive development of tourism in protected areas. Therefore, CONANP developed in 2006 its national strategy for development of sustainable and recreational tourism in the NPA of Mexico [6]. This strategy is an internal document that defines the guidelines and actions that the institution requirements to implement an optimally manage of tourism activity in the NPA. Also presented for the first time, the National Program of Tourism in NPA 2006-2012 with the purpose of coordinating the governmental counterparts and partners, non-governmental and private interests, and develop actions to implement in the short, medium and long term.

CONANP is focused to join efforts with interested stakeholders to expand tourism activities in protected areas that take place in a framework of economic, social and environmental sustainability. Thus, the diversity of climates and the complex geography of Mexico provide a considerable quantity of natural resources, which have been merged for the modality of tourism called adventure and ecotourism. Ecotourism is considered, particularly valuable in the NPAs with special natural attractions, such as a tool that provides the necessary financial resources for more effective management, motivating the government institutions to intensify measurements for regulations, and above all, to improve the conditions of the population living around the NPAs in order to decrease the pressure on natural resources. This diversity is enriched with a wide variety of cultural, archeological and gastronomical offerings, resulting in a merger for a framework of sustainable tourism development [7].

\section{Case of the State of Baja California Sur, Mexico}

The Mexican State of Baja California Sur (BCS) has the biggest coastline in the country (almost 3,000 Km), with the highest marine biodiversity, the lowest population density, and the highest percentage of NPAs in Mexico. This state has several types of natural systems and important economic activities at national 
and international levels. All of which has provided the perfect setting to create protected areas to guard the natural resources, and at the same time supporting socio-economic activities. BCS stresses the relevance of the coastal and marine environment in its social, economic, and academic life. Most of the population sits on the coastal strip. Currently, the State has 10 protected areas of various types and jurisdictions (Figure 2):

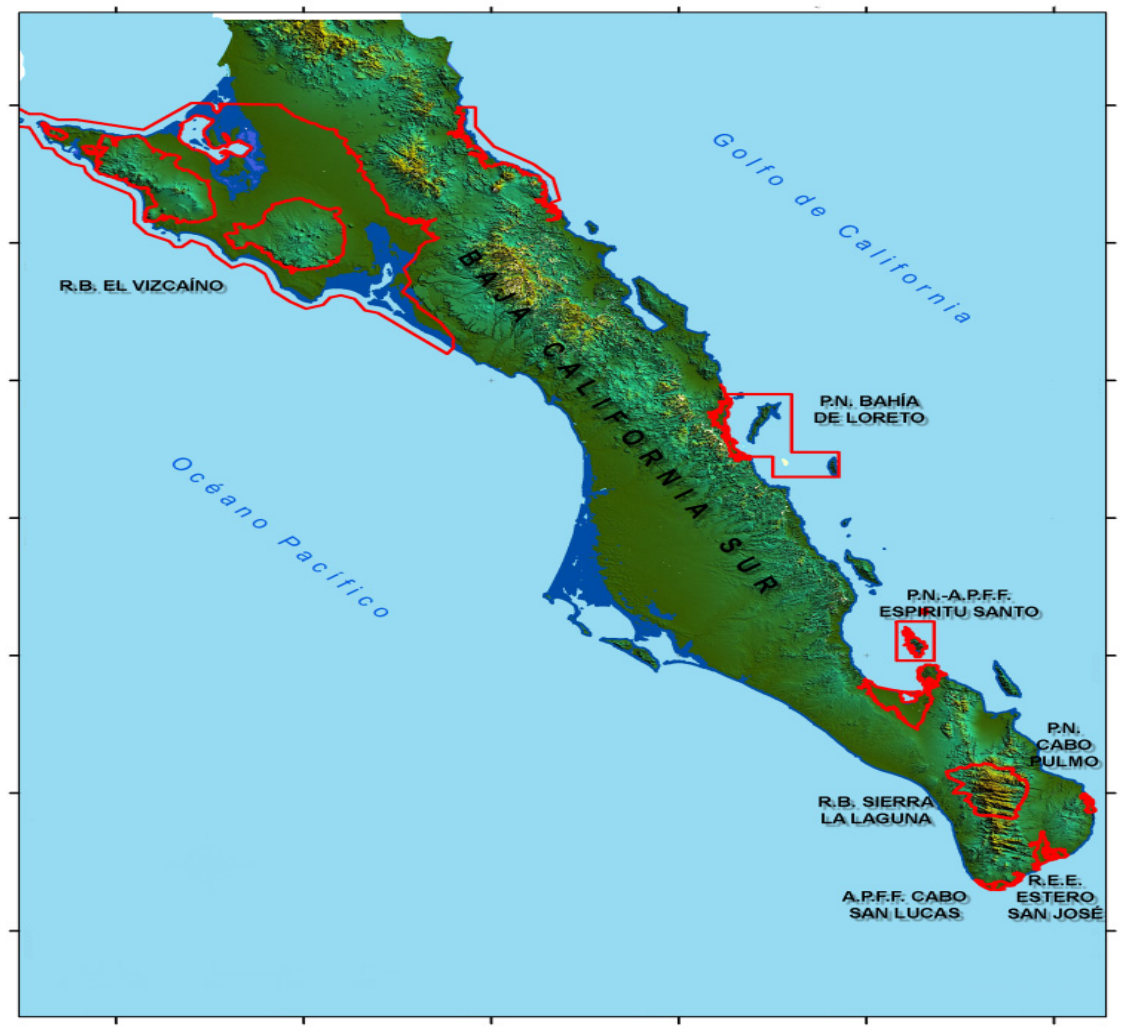

Figure 2: $\quad$ Natural protected areas in Baja California Sur.

Some of the most important NPAs are: Biosphere Reserve El Vizcaino, at the North of the state with 2.5 million of hectares, the National Park of Cabo Pulmo, which is the only coral reef of the Gulf of California, the Fauna and Flora Protection Area Gulf of California Islands, and the region of Cabo San Lucas Park Bay which has the highest amount of visitors through all of the year. Tourism has accelerated in recent years, becoming a fast-growing and important economy for the State and which could become the main source of development and employment in the region. During 2010, BCS demonstrated a growth of $12.3 \%$ in the total volume of tourists; $1,147,611$ tourists visited the area.

Many ministries of the Mexican Federal Government (SECTUR, SEDESOL, SEMARNAT, CONAFOR, SEDESOL, to mention just a few), considered the 
ecotourism as a tourism modality that would simultaneously conserve the NPAs, their natural resources and their areas of influence, as well as provide development and job opportunities for local communities. In order to promote responsible tourism, the CONANP has issued the so-called "Passport conservation" by which any tourist can visit any federal protected area as many times as he desires throughout the year [8]. The acquisition of this document is not required, but facilitates the control and management of the visitors interested in nature and the biodiversity, according to the capacity of each NPA. It is important to mention that almost all these funds are applied in the conservation and management of the NPA, and BCS is an example of the good results of the program, improving the conditions of the ecosystems and the quality of life of the locals.

\section{Outlook and conclusion}

The relationship man-NPA generates a specific problem that demands more integrated solutions based on a deeper knowledge of these relationships and elements. Its high production, high diversity and socio-economic importance of these resources, generate a broad perspective scheme that requires the scientific basis to support the proper research and management of natural resources contained in the NPAs. This is a dynamic process in which several factors should strengthen the options to meet the people's basic needs and improve their quality of life. These factors include the management of natural resources, empowerment of human beings and cultural values, information mechanisms, citizen participation, scientific and technological development approach, formulation of new legal and administrative plans, the direction of the economy, and the adoption and incorporation of ethical principles regarding environmental responsibilities.

The pressure on natural resources is rapidly increasing. The effect on NPAs and on natural ecosystems is notably manifested in the loss of species and in the disappearance, fragmentation, and degradation of habitats, landscapes, and ecosystems. These are the areas where wild species dwell and, in most cases, tend to decrease in numbers, and sometimes become extinct. In the specific case of Mexico the strategy for sustainable development should be founded on the generation of basic conditions that allow the compatibility - in a context of social and economic equity - between economic growth process and the protection of the environment and sustainable use of natural resources in NPAs. Within this framework, CONANP must play a leading role as a promoter of Mexico's development conditions, protecting the natural resources from possible destruction, recovering them or demanding that they need to be recovered, in every case that deals with activities within NPAs.

A consolidated system of NPAs, orchestrated by management programs and equipped with the necessary personnel for effective operations, will ensure an adequate promotion of these areas. The system will also allow establishing a link between conservation and development through jobs, revenues, and financing for the management and strengthening of conservation activities, both conventional 
as well as in their ecological modality. Focusing the sustainable tourism in NPAs, it is necessary to strengthen the coordination of the three levels of government to harmonize policies and regulatory outlines among municipalities, states, and the federal government. The system will also result in new forms of participation and co-responsibility of the different sectors of the local, regional, and national society as these sectors concur in its management.

When developing activities such as the Program of Tourism in Natural Protected Areas, it is important to consider and involve the human communities that live in and interact with them. Thus, the successful management of NPAs and the activities that occur in them, especially in the case of tourism, requires the integration of environmental issues, the communities that live in those areas and their participation in those activities of sustainable tourism. This also makes important the incorporation of environmental education, public information and communication, in the management plans [9]. The future management of NPAs in Mexico is difficult, but shows good prospects especially in the state of Baja California Sur. This is because the Mexican government has assumed the responsibility by establishing different instruments of environmental policies that include environmental programs based on regional analyses of Mexico's different hydrological, economic, social, and environmental characteristics [10].

\section{References}

[1] Arizpe, O. and Cobarrubias M., 2010. Sustainable tourism planning for the only coral reef of the Gulf of California. Sustainable tourism IV. Eds. C. Brebbia and F. Pinneda. WIT Transactions in Ecology and the Environment, Vol. 139, 2010.

[2] World Travel and Tourism Council, 2008. World-key facts at a glance, World Travel and Tourism Council, [http://www.wttc.org/eng/Tourism Research/Tourism_Satellite_Accounting/] (05.08.2008).

[3] Gamez, A., Ivanova A. and Montaño A. 2012. Turismo, sustentabilidad y desarrollo regional en Sudcalifornia. UABCS. Mexico.

[4] Kettunen, M., Bergöfer, A., Brunner, A., Conner, N., Dudley, N., Ervin, J., Gidda, S.B., Mulongoy, K.J., Pabon, L., Vakrou, A. 2010. Recognising the value of protected areas (in the economics of ecosystems and biodiversity (TEEB) report for policy-makers). Conference, Nature Conservation beyond 2010” May 27-29, 2010 Tallin, Estonia.

[5] Brenner L., 2006. Áreas naturales protegidas y ecoturismo: El caso de la Reserva de la Biosfera Mariposa Monarca, México. Relaciones. XVII (105):30.

[6] Estrategia nacional para un desarrollo sustentable del turismo y la recreación en las áreas protegidas de México (Consulta: Noviembre 2011). http://www.conanp.gob.mx/pdf_publicaciones/TurismoEstrategia.pdf

[7] Guerrero R., 2010. Ecoturismo mexicano: La promesa, la realidad y el futuro. Un análisis situacional mediante estudios de caso. El Periplo Sustentable. 
[8] Cobro de derechos CONANP (Consulta: 21 Noviembre 2011). http://www.conanp.gob.mx/acciones/cobro.php

[9] Arizpe M., O. Arizpe and A. Gamez. 2008. Communication and public participation processes in the sustainable tourism planning of the first capital of the Californias. Sustainable tourism III. Eds. C. F. Pineda and C. Brebbia. WIT Transactions in Ecology and the Environment, Vol. 115, 2008.

[10] Gutierrez, Y., 2013. Turismo Sustentable, Equilibrio, Mexico. Vol. 58: 1923pp. 